\title{
Too Much Trojan Technology
}

\section{Alison Carr-Chellman ${ }^{1}$}

Accepted: 6 October 2020 / Published online: 16 October 2020

(C) Association for Educational Communications \& Technology 2020

I fully support Dr. Kimmons' editorial (Kimmons 2020), "Current trends (and missing links) in educational technology research and practice." Dr. Kimmons has taken up a common recent theme among educational technology theorists. For some years, cries of missing, misdirected, and misaligned disciplinary work have been leveled against the educational technology space. Many of us in the field have made similar suggestions for future research and theory building. However, few of us have relied on data driven analyses. While there have been some citation analyses (Kirby et al. 2005; Ozcinar 2009) that are similar, Kimmons' approach is unusual. I agree with Kimmons' assertion that we in educational technology stand at the edge of COVID, racial injustice, global environmental threats, and deep political divides powerless to dramatically impact any of them, when we should have significant impact on all of them. Kimmons draws the obvious connection between online learning and COVID, but our unique confluence of learning and technology should be harnessed for equity, global warming, race relations, and political healing as well.

Many of us in the systemic change area have, for some time, battled with those who see technology as the "Trojan Horse;" the idea being that technologies are the focus-the way in the door. Once educational technologists as change agents gain access to schools, workplaces, corporations, universities, military training — really any context - they can then effect true systemic change or even a complete disintegration of any existing system of learning (Bull 2016). Instructional design consultants are familiar with the excitement leaders express when we mention a new tool that might help to effect the desired change, as well as the glazed-over look we get when we talk about a new approach or, even worse, organizational change. Indeed, new technologies are seductive. This same technophilia exists for journal editors, grantors, conference organizers, even colleauges. Technology is sexy. And

Alison Carr-Chellman

acarrchellman1@udayton.edu

1 University of Dayton, Dayton, OH, USA
Kimmons' analysis bears this out. The trouble is, bait and switch approaches rob us of any moral authority through which we can address these deeper issues.

Kimmons acknowledges that the data process he has used may not give us a complete picture. And I would have to agree with his assessment. By eliminating data that involved general terms in the field like learning, research methods, and contexts, I worry that we may have created an analysis that simply confirmed what we set out to, rather than creating as open an analysis as possible. Did the analysis process itself eliminate some of the scholarship we were seeking around learning, practice, broad social issues, application, universal design and so forth? This concern reaches its pique for me when Kimmons asks readers to consider that "a gap exists between research and practice, with researchers and journal reviewers exhibiting a technophilic flow toward the newest technologies (rather than those that are being used by institutions to solve pressing problems)?" Of course, this may be possible, in fact I believe his point is well made, however the data upon which the assertion rests may be weaker than we'd like. I would encourage more robust data scraping procedures in future research on this topic.

Overall, I am definitely on Kimmons' side. I fundamentally agree that we are 'amusing ourselves to death' with our technology toys (Postman 2005). When we take this easy road, this cheap approach, we abdicate our role as leaders. And when we leave the leader path, we disqualify ourselves from being able to address ongoing socio-cultural issues like those outlined in Kimmons' editorial. In closing, I adapt an antitechnology statement from Wendel Berry's (2018) essay on computer resistance:

I have seen advertisers seducing users into the belief that we can solve their problems by buying yet another piece of expensive equipment. I know about their propaganda. It doesn't impress me as it does not bring me one step nearer to anything that does matter: equity, justice, peace, ecological health, political honesty, family and community. 


\section{References}

Berry, W. (2018). Why I am not going to buy a computer. In The world ending fire: The essential Wendell Berry. Berkeley: Counterpoint Press.

Bull, B. (2016). Yes, educational technology is a Trojan horse. It has been one for centuries. Etale. May 20. Retrieve 9/19/2020 from: https:// etale.org/main/2016/05/20/audrey-waters-right-conspiracy/.

Kimmons, R. (2020). Current trends (and missing links) in educational technology research and practice. TechTrends, 64(6).

Kirby, J. A., Hoadley, C. M., \& Carr-Chellman, A. A. (2005). Instructional systems design and the learning sciences: A citation analysis. Educational Technology Research and Development, 53(2), 37-47. https://doi.org/10.1007/BF02504856.

Ozcinar, Z. (2009). The topic of instructional design in research journals: A citation analysis for the years 1980-2008. Australasian Journal of Educational Technology, 25(4). https://doi.org/10.14742/ajet.1129.

Postman, N. (2005). Amusing ourselves to death: Public discourse in the age of show business. New York: Penguin Random House.

Publisher's Note Springer Nature remains neutral with regard to jurisdictional claims in published maps and institutional affiliations. 